\title{
Case Studies, Cuts, and Critical Information Literacy
}

\author{
Reece Steinberg \\ Ryerson University \\ rsteinberg@ryerson.ca
}

\begin{abstract}
Post-secondary institutions are responding to cuts in government funding by prioritizing skillsbuilding directly related to employment. Conservative governments ignore employers' call for transferable skills in new graduates, and use funding cuts to pressure educational institutions' focus. Librarians face the challenging task of offering instruction in both specific technical skills and transferable thinking skills in a limited time period. Critical information literacy is increasingly included as part of instruction in post-secondary libraries, in addition to technical use of library resources. This paper includes practical examples of critical library instruction using case studies, and explores the relationship between case studies and critical information literacy. Case studies in library classes or workshops fit within required guidelines for careerfocused learning and practical skills-building while providing opportunities for students to engage in analysis of information. Cases lend themselves well to progressive, learner-focused, and flexible modes of instruction. This paper argues for case studies as a radical, relevant tool in post-secondary library teaching.
\end{abstract}

\section{Introduction}

Critical information literacy is increasingly included as part of instruction in post-secondary libraries, alongside technical use of library resources. Information literacy is radical when it facilitates students' participation in questioning assumptions about academic structure and learning, as well as students' own biases, social constructs and popular opinions (Gregory \& Higgins, 2013; Whitworth, 2014).

Canadian post-secondary library instruction emphasizes these skills while, at the same time, provincial governments reduce and constrain educational funding. Employers speak openly about the need for transferable skills in new graduates, but are ignored by timidly conservative governments who use funding cuts to pressure educational institutions to focus on job-specific skills. Many post-secondary institutions are responding to the climate of growing scarcity by prioritizing learning that relates directly to employment. Librarians face the task of simultaneously meeting all of these needs by offering instruction in profession-oriented skills, technical skills, and transferable critical thinking skills in a limited time period. This is challenging in short, "one-shot" library instruction sessions. I propose case studies as an engaging way to accommodate the limits of time while facilitating information literacy instruction responding to professional and academic needs while building critical faculties. Case studies are stories constructed to examine behaviour or circumstances, or imagine scenarios; an unprepared politician's remark catches wide media attention for being tone-deaf, or

Journal of Contemporary Issues in Education, 2020, 15(1), pp. 51-64. 
inconsistent adherence to policy in a shopping mall leads to a breach of security. They can be gripping, practical and thought-provoking. Case studies in library workshops provide opportunities for workplace learning and practical skills as well as critical analysis and information literacy skills-building. Cases lend themselves well to progressive, learner-focused, and flexible critical pedagogy. This paper includes practical examples of critical library instruction using case studies, and explores the relationship between case studies and critical information literacy in the current context of education in Canada.

\section{Case Studies as a Response to Economic and Political Pressures}

Ironwood Forest Community College is a large suburban institution that draws students from the surrounding metropolitan area, many of them commuting adult learners. Their provincial government announced financial cuts to all post-secondary institutions, and is introducing performance-based funding: additional funds that would be distributed to institutions with graduates that had the highest average income in their chosen field within 4 years. Ironwood's upper management communicated that the severe cutbacks would affect areas not tied to the college's mission and strategy of graduate success. This nudged managers to prioritize evaluation and assessment in order to prove they were contributing to graduate performance. The college library, like other departments, aimed to demonstrate their value through their annual report and other communications. Teaching librarians believed that they were providing valuable and useful information literacy (IL) instruction, though some of the students seemed unable to relate it to their workplace ambitions. Library management found it challenging to demonstrate how the instruction was directly connected to graduate earning or career advancement. Search technique instruction was part of the sessions, and in fields such as marketing, could be used in future workplaces, but in some fields - dental assisting, personal support work, and others - graduates would not necessarily be expected to perform their own research on a regular basis, or have access to databases. Teaching librarians wanted to add materials to their sessions that would highlight the practical nature of their IL workshops, and directly connect the critical thinking skills students were developing to their future careers. Adding additional time on to the sessions was not possible, either for the librarians or the classes. Teaching librarians were already stretching their resources to be able to provide current levels of in-class instruction.

After a few pilot sessions, the librarians incorporated topical case studies into their sessions. Students learned the mechanics of searching using cases and discussed information literacy in the context of the case studies as well as supporting information that they found in library databases. The librarians drew links between class outcomes and career success, as the cases provided workplace scenarios related to the students' programs, inviting students to consider potential information-based reactions to professional situations. The students were more engaged in class, and their feedback was positive, many having noted that they appreciated examples of how information literacy plays a role in their chosen fields.

This case on Ironwood Forest Community College is an amalgamation of real situations and demonstrates some of the economic and political issues, time constraints and other factors that

Journal of Contemporary Issues in Education, 2020, 15(1), pp. 51-64. 
challenge post-secondary librarians providing library instruction. One option that can include workplace and academic, technical and critical learning objectives, while satisfying librarians and educators and engaging students in a short time frame is the use of case studies in library instruction.

\section{Information Literacy in Libraries}

Information literacy instruction in academic libraries has grown over the past 20 years and was named as a critical thinking skill by the American Library Association in 1989 (Gilstrap \& Dupree, 2008). A heightened interest in, and perceived need for IL is a response to political and technological change which led to massive shifts in communication, information creation and access (Baird \& Parayitam, 2019; Copenhaver, 2018, Trembach \& Deng, 2018). Trends in postsecondary education include a growing acknowledgement of students' need for research, and education in locating resources and establishing relevance to their need (Junisbai, Lowe, \& Tagge, 2016). Trembach and Deng (2018) state that "information literacy instruction in the twenty-first century is... an integral part of virtually every area of knowledge" (p. 298). Postsecondary librarians provide instruction in technical and critical information use, often simultaneously. Students practice database searching and creating search strategies while evaluating the resources they find. In his paper examining the implications of the lack of IL and related concepts in library mission and vision statements, Perret (2018) poses that institutions have given increasingly greater weight to these statements in recent years, yet only $24 \%$ of the large American university libraries surveyed included the concept in their vision or mission. Does failing to include information literacy or other education requiring critical thought expose libraries to political and economic pressure toward solely technical instruction? Performancebased funding to universities can encourage unintended negative consequences (Hagood, 2019; Natow \& Dougherty, 2019). When this funding is tied to graduates' (short-term) financial and career accomplishments, how do post-secondary institutions (and their libraries) respond, given that performance-based funding may contribute to the homogenization of post-secondary institutions, and impact research focuses (Woelert \& McKenzie, 2018)?

Case studies encompass the potential for practicing critical as well as technical skills, saving lean time which is a limiting factor in IL instruction, where critical literacy skills are in danger of losing to mechanics. Library instruction is restricted by severe time constraints, originating from all directions; in-class instruction is provided often by professor request, with the length of time determined by the professor (Nicholson, 2016). One-off 30-90 minute classes for certain courses, or even for entire programs are common. Some regulated programs, such as in the health sciences, have very specific hourly requirements for in-class time, leaving little time for library instruction. Librarians have limited time available and depending on the number of librarians and classes, this too can be a limiting factor. Trembach and Deng (2018) state that the length of time allotted to library instruction "presupposes an almost instantaneous transfer of information" (p. 299). Given the time constraints, goals of library instruction are frequently lofty. Library instruction requires some level of customization to a course or project for it to be meaningful and applicable to students' specific needs, in terms of topic and level of technical and research skills 
required. This exacerbates time pressures in class, as well as librarians' advance preparation time.

\section{Literature Review}

A close connection between critical thinking and information literacy instruction has been established by 30 years of scholarly writing as well as their intertwined nature and shared goals (Johnson, Lindsay, \& Walter, 2008). Critical thinking in an educational context includes judgement, scepticism, originality, sensitive reading, rationality, activist engagement with knowledge and self-reflexivity (Moore, 2013). These are processes students undertake when practicing information literacy, and used together help to provide a rich, critical, and creative toolbox for making, evaluating and understanding information. Investigating the potential of critical thinking to provoke radical responses, a feminist perspective challenges the notion of critical thinking as merely a skilset meant to produce, and focuses on how critical thinking feels. Developing literacies ("knowledge practices") contribute to shifting emotions, and a fundamental (radical) change in learners' outlook (Danvers, 2015). This shifting, relational view of critical thought critiques a narrow, masculine-centric view of critical thinking as purely rational, or a set of skills, and instead emphasizes its whole-person construction, and guides the reader to question what critical thought does, rather than is.

Students' skills and knowledge are acknowledged when information literacy instruction questions authority, encouraging learners to use their lived experience and critical faculties to examine and evaluate information sources (Critten, 2016; Whitworth, 2014). This diverts information literacy away from a rigid dedication to conventional expertise, without space to challenge authority or stray from binary thinking (Critten, 2016). Gregory and Higgins (2013) outline a critical praxis for IL instruction, one that takes political and social contexts of academic resources into account in post-secondary classrooms. It encourages critical thought about creating and using resources, and about the structures and systems that contributed to creating or elevating the sources. Critical pedagogy for academic IL necessitates student "dialogue, reflection, and engagement in real-world problems" (Gregory \& Higgins, 2014, p. 102; emphasis added).

Case studies present real or realistic stories to students, and are used in a variety of disciplines including health sciences, business, law, and others to engage students in active learning and critical thought, moving away from passive lecture-style education (Burko, 2016; Popil, 2011). There are a variety of teaching methods that employ case studies (Burko, 2016; Hull, 2018). Hull (2018) outlines interrupted cases used in the sciences, where students are presented with only some information, and must create and adjust hypotheses based on emerging information. She also provides a unique example of students creating their own cases by completing a template with blank spaces. Both of these are particularly suited to IL instruction, as they provide opportunities for information discovery and analysis. Lapoule and Lynch (2018) link the use of case study pedagogy and cases in research, noting that the use of case studies in classrooms enhances research practices and vice-versa, which could be explored in an information literacy context. Whitworth (2014) explores a radical approach to IL using narratives as a tool to

Journal of Contemporary Issues in Education, 2020, 15(1), pp. 51-64. 
encourage learners to explore viewpoints and experiences that vary from their own, stating "within narratives, one can see signs of the information narratives that have shaped them" (Chapter 8). Whitworth (2014) includes that a narrative method may also help learners locate how their own views change over time.

Jones (2016) describes a case-study approach to information literacy in an English secondary school. The course design provides the student with an opportunity to conduct ongoing research into a variety of viewpoints relating to the cases, and provoked discussion. The librarian's role was to facilitate students' sharing of experiences and thoughts, conduct research and examine media, in collaboration with the course's teacher. Scant mention of case study teaching exists in critical information literacy or other library instruction literature, though case studies are frequently used in information literacy and librarianship literature to illustrate a point or as a research method (e.g. Morrissey \& Given, 2006; Gregory \& Higgins, 2013; Whitworth, 2014). Saunders (2017) names case studies as a tool that could be used in business information literacy instruction to provide workplace information literacy using real world sources for more academically-focused classes. Saunders acknowledges the challenges librarians face when tasked with providing workplace-focused as well as academic information literacy instruction, but does not address information literacy from a critical perspective or interrogate neoliberal agendas or infrastructure that may press librarians to provide specific types of instruction. Jacobs (2016) writes of student engagement in the context of critical library pedagogy. She provides an example in which student discussion following an activity about information literacy led to similar points as she would have provided on slides, but that critical pedagogy rests on student agency and discovery in learning, which are evident in the example activity. In contrast, she posits that a lecture-style class on the same points treats students as passive, awaiting the input of knowledge. Popil (2011) discusses case studies as a teaching method that can assist educators working to avoid a passive lecture experience. She writes about nursing education - not information literacy - but comes to the same conclusion as Jacobs that active engagement in learning gives students the opportunity to discover the significance of information, creating an environment where they can use critical thinking skills. She promotes teaching with case studies as a strategy.

Both Jacobs (2016) and Nicholson (2016) include time as a pain-point in critical information literacy instruction. Jacobs alludes to lack of time as a reason librarians believe they cannot include critical information literacy in their instruction, and provides an example of an activityfocused class that provokes critical thought in a short time period. Nicholson begins by stating that the "one-shot [library instruction] is all about time: how to negotiate with faculty for additional class time, how to manage classroom time effectively ... how to "stretch" time" (2016, p. 25). She urges adoption of slow scholarship outside of the 50-minute one-shot library instruction, but acknowledges the importance of the short, single library instruction in maintaining the library's existence in institutions situated in a capitalist academic environment. In discussing slow scholarship and the limitations of time, Nicholson suggests that creative alternative teaching methods used in the brief, individual library instructions sessions is a form of resistance to skills-focused instruction, while also noting that the neoliberal roots of information literacy may be challenging to escape. Gregory and Higgins (2018) expand on Journal of Contemporary Issues in Education, 2020, 15(1), pp. 51-64. (c) Author(s), Creative Commons Attribution 4.0 (CC BY 4.0) licence http://ejournals.library.ualberta.ca/index.php/JCIE doi 10.20355/jcie29414 
libraries and librarianship's rise in America, and its ongoing and historical relationship to capitalism. They write of Melvil Dewey (inventor of the Dewey Classification System) envisioning libraries as molded in the image of businesses and the marketplace, where patron interactions are transactions, information is currency, and efficiency is prized.

Seale (2016) acknowledges the often-compromised conditions of information literacy instruction, alluding to time constraints and large class size, as well as scheduling that is less than ideal: often students receive instruction before understanding or receiving assignments requiring research. She offers strategies for incorporating critical pedagogy into classroom limitations and states that the goal of critical pedagogy is "empower[ing students] to ask questions and construct their own viewpoints and meanings" (p. 230). Seale concludes that explicit critical librarianship can enhance faculty and student acceptance of critical pedagogy in some circumstances, encouraging librarians to covertly offer small, critical changes to programs when a welcome is less forthcoming.

Prescott (2016) examines antiracist pedagogy as a facet of critical information literacy, providing both background and practical information, including encouragement to begin antiracist pedagogical practices by making small changes to existing curriculums. Seale (2016) concurs, noting that small changes in pedagogical approach can make a large difference to library instruction, and incorporate both the instruction that instructors request, as well as critical information literacy. She goes further to state that these modifications to instruction may influence some faculty members, opening the doors to richer opportunities for critical librarianship.

Shaw (2014) discusses critical thought in relation to music education, an area of study that, like library instruction, has the potential to emphasize solely technique, or technical skills. He argues music education greatly improves in significance when critical thought is incorporated into the class. Shaw writes that learning to think critically provokes fundamental (radical) changes in classes and individuals in his technical musical education classes.

Critical thinking and instruction designed to foster it can take place in a variety of settings including in avenues typically considered technical. Critical thought may be perceived very differently by individuals and in different contexts; as demonstrated above, it is widely experienced as a mechanism for radical change in thought, development and perception.

\section{Performance Funding \& Time Scarcity in Education}

New education policies affecting Canada's post-secondary institutions carry direct reductions in provincial funding or a serious threat of a reduction in the form of performance funding (Beach \& Milne, 2019; Lang, 2017, Fullerton, 2019). While government expectations vary by province, there is some degree of alignment with government objectives that universities agree to when accepting government funds (Eastman et al., 2018). Tying provincial funding to graduate employment and earnings puts a focus on one aspect of educational outcome, potentially causing unintended consequences. These include an increase in homogeneity among post-secondary

Journal of Contemporary Issues in Education, 2020, 15(1), pp. 51-64. 
institutions, specifically regarding their educational approaches and organizational structure, including both research-intensive universities, and those that are not in Australian performance funding programs in the post-secondary sector (Woelert \& McKenzie, 2018). As well as a decrease in admission of populations of students deemed to be less likely to meet specific criteria, and a reduction in standards for grades and graduation (Hagood, 2019; Natow \& Dougherty, 2019). Providing incentive for institutions to increase their graduates' short-term earning and employment could be causing a reaction in universities to develop more easilymeasurable technical skills directly related to employment rather than transferable skills. Even when other metrics for universities (long-term student satisfaction) are ignored, it is unclear that promoting hard skills leads to higher lifetime earnings. In an environment of collaboration and rapid obsolescence of specific skills, employers are seeking employees with transferable skills. In a study of 50 medium to large employers, the second most desired trait of 21 options was critical thinking/problem solving. Only interpersonal skills were considered more important in a new employee (Baird \& Parayitam, 2019).

Librarians feel pressure to balance student learning of specific technical skills and transferable thinking skills, while offering learning situations directly relating to professional skills all in a very limited time period. They must meet the academic needs of the instructors whose classes they attend often at the discretion of the instructors, and whose academic outcomes may require specific instruction (Nicholson, 2016; Saunders, 2017; Seale, 2016). In that respect librarians join students and faculty in attempting to justify their use of time, and make effective use of time, perhaps beyond the bounds of what is reasonable (Nicholson, 2016). Information literacy developed in the context of capitalist academic institutions, has a skills-focused neoliberal skin, if not heart (Nicholson, 2016). Nicholson argues that this is why librarians have "struggled to move beyond the one-shot model" (p. 27): because the short, single instruction is suited primarily to superficial and skills-based instruction.

\section{Discussion}

Case studies are profession-oriented parables, stories where something happens designed to examine why or how a series of events occurred. Communication breaks down in a hospital and a patient receives an incorrect medication, or a social media campaign is poorly-timed and fails to attract attention. Cases connect students with real life learning and practical skills, while helping them use technical information-seeking practices. When cases pose a question or ask for a solution, they are open and avoid one right answer. They provide a venue for meaningful analysis of information, its source, the parties who benefit from the information being propagated, and other lines of thought. Cases can challenge students to use critical thinking skills to determine the causes of a series of events, what could have disrupted the events, and information or data they would benefit from accessing in order to make further predictions.

Cases lend themselves well to progressive, learner-focused, and flexible modes of instruction, such as flipped classrooms. They are available on a variety of subjects and disciplines, and range from short video clips to thick documents. This increases opportunities for librarians to follow Universal Design for Learning (UDL) principles - a framework which incorporates multiple modes of teaching and communication to increase access to learning, and promote diversity in

Journal of Contemporary Issues in Education, 2020, 15(1), pp. 51-64. 
education (Tobin \& Behling, 2018). Cases provide ample opportunity to practice use of search techniques in library databases and catalogues, fulfilling technical requirements. Critical analysis and comparison between online cases provide students with opportunities to hone evaluation skills and room to stretch their critical thinking skills by questioning information authority. This can extend to questioning structures in their environment and the sources of their information $-\mathrm{a}$ radical act that undermines and challenges neoliberal educational constraints.

\section{Information Literacy \& Market Research}

Robin is a business librarian at Friesen University, a mid-sized urban institution with a strong business program. He will be providing a refresher to a class of 50 second-year business students who attended a general introduction to business resources and information literacy the previous year. Robin chooses a case study with a flipped classroom for this 1-hour session and hopes to engage students while helping them exercise their critical thinking skills. The librarian provides the professor with a 7-minute video clip to share with the class. The clip is about a business providing fantasy sports games played on social media networks and aimed at developing mental agility while reducing social isolation in people with depression. The students are instructed to watch the video before class, and bring one industry report or analysis relevant to an aspect of the topic to class. The specific topic is intentionally multifaceted in order to increase the likelihood of students bringing a range of different resources.

This structure, adapted from Prud'homme-Généreux et al. (2017) and Herreid and Schiller's (2013) plans for STEM flipped classrooms, is organized in order to support the fictional librarian's aims. Case study teaching engages students while helping them to develop criticalthinking skills (Herreid \& Schiller, 2013). Flipped classrooms have been championed for a wide variety of reasons; most relevant in this instance is that it provides the time-starved librarians more time for interactivity in class, as opposed to lecturing, and engages learners (Herreid \& Schiller, 2013). Once in class, Robin could break the class into groups of four, have the students briefly discuss the reports/articles each had brought, and what additional information they would want in order to be able to predict if the game was likely to be a successful venture, determine its ideal target market, or fulfill another goal. The class could come back together for Robin to demonstrate techniques for finding additional information they would want to supplement the reports and analyses they had, as well as discuss questions in the larger group. This example provides students with multiple forms of learning - individually outside of class, in class in small groups as well as in the larger class; it uses a video, industry report/analysis and potentially articles, additional reports and analysis, data and statistics, demographic information, and other resources as supplementary resources. It helps marketing students connect what they are learning in the library class to real decisions and research they may need to perform on the job, a fun yet realistic scenario, and importantly the opportunity to figure out what else they need to know.

\section{Medical Database Searching for Nursing Students}

Tyrone is the health sciences librarian at a large community college with a strong nursing program. His challenge is to provide adequate instruction in advanced searching using medical

Journal of Contemporary Issues in Education, 2020, 15(1), pp. 51-64.

(c) Author(s), Creative Commons Attribution 4.0 (CC BY 4.0) licence

http://ejournals.library.ualberta.ca/index.php/JCIE

doi 10.20355/jcie29414 
databases to two full classes simultaneously in one hour. Each class consists of 50 students, for a total of 100 attending his session. The program is extremely structured in order to conform to professional regulations. The library instruction session is scheduled early in the semester, before students have to start working on the assignment directly related to the searching, leaving them less motivated to engage in the session. The restricted time frame, class size and the style of the lecture theatre provide him with little opportunity for interaction with individual students, and limited group activity options. In the past, students have appeared uninterested in the session, and easily distracted by their phones. Tyrone is unsure if they understand the sessions, and find them slow, or are completely lost. The students are not given a library assignment because their professor acknowledges they are already overburdened with assignments. This adds to the challenge of capturing the students' interest, as they do not have an immediate use for the material in the session. They regularly require individual assistance later in the semester when they are working on their papers, largely on the material covered in the session. Tyrone aims to introduce a case into the session in order to set the stage for why a nurse would do research: the case provokes interest, as the students can imagine that the patient described is theirs. Health sciences case studies generally include factors such as multiple diseases, challenging circumstances, or other irregularities. The cases are often chosen for a reason: because they are unusual. This provides librarians (and students) with options to choose from when conducting further research on the topic. A case study, low on health sciences' hierarchy of research evidence, provides librarians with an opportunity to introduce the concept of different levels of reliability of evidence, as well as a reason to search for related information with greater reliability (higher up the pyramid of evidence), such as a systematic review or randomly controlled trial.

Tyrone sets the stage in class by briefly describing a case study, which he found in preparation for the class. CINAHL (Cumulative Index to Nursing and Allied Health Literature) and other health databases provide the option of limiting results to case studies only, and include a wide variety of cases to choose from. Tyrone chose "Bell's Palsy: Diagnosis and Prioritization of Care" from the trade publication Pennsylvania Nurse, describes it, and then uses polling software to share a link to it with students, allowing them to easily email the case to themselves using their phones (Edgar, 2017). He lets them know they will be invited to use the software at various times during the session, and that he will be using it to verify they understand the information he is presenting towards the end of the class. He adds that if they are having trouble understanding then he is happy to provide further explanation, and if they understand they will have the option to let him know so that he can expand on other areas, or finish the class early. This provides incentive to the time-pressured students, motivating them to pay attention and participate in the polling. The librarian then gives the students three options for further research in combination with Bell's Palsy, all of which stem from the article: steroid treatment, herpes viruses, and depression. All three options are valid responses; choice by poll voting helps to engage students and give them some agency in their learning. The students choose depression, so Tyrone uses that example to search CINAHL, searching first for Bell's Palsy, demonstrating the option to search for CINAHL subject headings, and specific features of the database. He then starts a new search to look for depression, and finally shows students how to combine the searches. Tyrone encourages students to ask questions through the polling software, pausing to give them time to 
write in. He circles back and reminds students of the pyramid of evidence, and provides a multiple choice question to verify their comprehension, then provides a further explanation if necessary. This polling provides him with valuable information about their level of understanding, while engaging the students. Tyrone uses the software to ask a few other multiple-choice questions to assess student understanding of other aspects of the session, including combining searches, and searching for subject terms. In each case, he asks what step the students should take next. For example, when searching for Bell's Palsy:

1. To begin searching CINAHL for Bell's Palsy, the most effective option is to:

a. Use the drop-down box to select "all text"

b. Select "Suggest Search Terms" and keyword search

c. Explode the term

d. Combine searches from your search history

He also asks for quick feedback from students at the end of the session. Many provide positive feedback about the interactive aspect of the session, as well as the practicality of the case study.

Professions such as policing, journalism, and many others include creating frequent, routine documentation of heavy importance in limited time. This documentation represents the values of the individual and profession, and has the power to strongly impact the lives of people connected with it (Cotugno, 2018). Librarians can use this set of practical circumstances to provide a case scenario relevant to the students' field of study - criminology students imagining themselves as police officers writing an incident report, or a journalism student writing a news brief based on a specific incident outlined in the case. The students' task would be to find quality information related to the case that could assist them with writing a report or news story, using library resources and search techniques covered in class. This could be a fictional report but ideally would be tied to an upcoming assignment writing this type of report for their class.

Professional programs lend themselves easily to incorporating case studies in the classroom in part because most students in these programs endeavour to work in the same field or profession. There are also rich collections of case studies that lend themselves to academic/research fields including complete books on topics ranging from emotion in literary studies to resistance in underground American music to 20th-century women's authorship to film adaptations of Hollywood-era screen plays, and endless others (e.g., Gail, 2018; Ingeborg et al., 2017; Neale, 2017; Morra, 2014). Similar to the business case example above, these cases could be used to provide context for library research, and engage students in figuring out what information in addition to the case study would be helpful in forming a research question, or answering questions posed by the case. The importance of guiding students in the practice of developing ideas about the type of information they would like to find, substitutes for the "ideal" resource item, and techniques in developing research queries cannot be underestimated and yet are sometimes missed in library instruction. Librarians working in collaboration with professors improve student information literacy and research skills outcomes over professors working without librarians (Lecea \& Perez-Stable, 2019). Student skill increases when librarian IL instruction is offered at various levels and in multiple courses throughout students' educational career (Lecea \& Perez-Stable, 2019). Academic information literacy competencies may be transferable to workplace information literacy, but librarians who make the connection explicit may be more successful at capturing the attention of educators and learners (Saunders, 2017).

Journal of Contemporary Issues in Education, 2020, 15(1), pp. 51-64. 


\section{Conclusion}

Thoughtful use of case studies in post-secondary IL instruction is a viable response to pressures on librarians to demonstrate their contribution to a narrowly-defined concept of student success based on short-term earnings. Case studies can enliven and engage students, and demand no concessions in regard to the flexibility of instruction styles. IL activities using case studies can help librarians provide an environment that employs students' critical thinking skills, and supports critical pedagogy. This article outlines several ideas for incorporating cases into professional fields, as well as opportunities for IL instruction to academic/research-focused fields of study. Librarians providing post-secondary information literacy instruction in a wide variety of disciplines have case studies available as tools to address learning objectives that may be a combination of professional, academic, technical and critical-thinking. Cases can be long or very brief, lend themselves to short one-shot library instruction, and can be incorporated into existing instruction sessions. Librarians and other educators can question and contest neoliberal funding cuts to education by employing tools to foster critical, creative analysis in IL even and especially when it is unexpected. Critical information literacy is a radical act that provides space for students to question and critique information around them, including information from social and political structures that contribute to Canada's current political situation. 


\section{References}

Baird, A. M., \& Parayitam, S. (2019). Employers' ratings of importance of skills and competencies college graduates need to get hired. Education + Training, 61(5), 622-634. https://doi.org/10.1108/ET-12-2018-0250

Beach, C. M., \& Milne, F. (2019). Ontario post-secondary education funding policies:

Perverse incentives and unintended consequences. (QED Working Paper Number 1424). Kingston, ON: Economics Department, Queen's University. Retrieved from https://www.econ.queensu.ca/sites/econ.queensu.ca/files/wpaper/qed_wp_1424.pdf

Burko, L. M. (2016). Using the case study method in teaching college physics. The Physics Teacher, 54(7), 413-415. https://doi.org/10.1119/1.4962777

Copenhaver, K. (2018). Fake news and digital literacy: The academic library's role in shaping digital citizenship. The Reference Librarian, 59(3), 107-107. https://doi.org/10.1080/02763877.2018.1484412

Cotugno, M. (2018). Using the case study method to improve criminal justice students' critical thinking skills. Journal of Criminal Justice Education, 29(4), 597-622. https://doi.org/10.1080/10511253.2018.1426775

Critten, J. (2016). Death of the author(ity): Repositioning students as constructors of meaning in information literacy instruction. In S. McNicol (Ed.), Critical literacy for information professionals (pp. 19-30). London: Facet Publishing.

Danvers, E. (2015). Criticality's affective entanglements: rethinking emotion and critical thinking in higher education. Gender and Education, 28(2), 282-297. https://doi.org/10.1080/09540253.2015.1115469

Eastman, J., Jones, G. A., Bégin-Caouette, O., Li, S. X., Noumi, C., \& Trottier, C. (2018). Provincial oversight and university autonomy in Canada: Findings of a comparative study of Canadian university governance. The Canadian Journal of Higher Education, 48(3), 65-81.

Edgar, D. M. (2017). Bell's palsy: Diagnosis and prioritization of care. Pennsylvania Nurse, 72(3), 6-13. Retrieved from CINAHL.

Fullerton, M. (2019, April 18). "University and college funding." Legislative Assembly of Ontario. Hansard Transcripts. 42nd Parliament, 1st session. Retrieved from the Legislative Assembly of Ontario website: https://www.ola.org/en/legislativebusiness/house-documents/parliament-42/session-1/2019-04-18/hansard

Gail, D. (2018). Weird American music: Case studies of underground resistance, BarlowGirl, Jackalope, Charles Ives, and Waffle House Music. Munich, Germany: Universitätsverlag Winter.

Gilstrap, D. L., \& Dupree, J. (2008). Assessing learning, critical reflection, and quality educational outcomes: The critical incident questionnaire. College \& Research Libraries, 69(5), 407-426. https://doi.org/10.5860/crl.69.5.407

Gregory, L., \& Higgins, S. (Eds.). (2013). Information literacy and social justice. Sacramento: Library Juice Press.

Gregory, L. \& Higgins, S. (2018). In resistance to a capitalist past: Emerging practices of critical librarianship. In K.P. Nicholson \& M. Seale (Eds.), The politics of theory and the practice of critical librarianship (pp. 21-38). Library Juice Press.

Journal of Contemporary Issues in Education, 2020, 15(1), pp. 51-64. 
Hagood, L. P. (2019). The financial benefits and burdens of performance funding in higher education. Educational Evaluation and Policy Analysis, 41(2), 189-213. https://doi.org/10.3102/0162373719837318

Herreid, C. F., \& Schiller, N. A. (2013). Case studies and the flipped classroom. Journal of College Science Teaching, 42(5), 62-66.

Hull, K. (2018). Using student-generated case studies to teach respiratory physiology. Advances in Physiology Education, 42(2), 251-255. https://doi.org/10.1152/advan.00147.2017

Ingeborg, J., Gudrun, T., Susanne, K., \& Sabine, S. (2017). Writing emotions: Theoretical concepts and selected case studies in literature. Bielefeld, Germany: transcript Verlag. https://doi.org/10.2307/j.ctv1wxt3t

Jacobs, H.L.M. (2016). Falling out of praxis: Reflection as a pedagogical habit of mind. In N. Pagowsky, \& K. McElroy (Eds.), Critical library pedagogy handbook (pp. 1-8). Chicago: Association of College and Research Libraries, a division of the American Library Association.

Johnson, C. M., Lindsay, E. B., \& Walter, S. (2008). Learning more about how they think: Information literacy instruction in a campus-wide critical thinking project. College \& Undergraduate Libraries, 15(1-2), 231-254. https://doi.org/10.1080/10691310802177267 Jones.R. (2016). Curricular and extra-curricular opportunities to engage school students in critical literacy in England. In S. McNicol (Ed.), Critical literacy for information professionals (pp. 105-113). London: Facet Publishing.

Junisbai, B., Lowe, M. S., \& Tagge, N. (2016). A pragmatic and flexible approach to information literacy: Findings from a three-year study of faculty-librarian collaboration. The Journal of Academic Librarianship, 42(5), 604-611. https://doi.org/10.1016/j.acalib.2016.07.001

Lapoule, P., \& Lynch, R. (2018). The case study method: Exploring the link between teaching and research. Journal of Higher Education Policy and Management, 40(5), 485-500. https://doi.org/10.1080/1360080X.2018.1496515

Lang, D. W. (2017). Fiscal incentives, Clark's triangle, and the shape and shaping of higher education systems. Policy Reviews in Higher Education, 1(2), 112-138. https://doi.org/10.1080/23322969.2016.1246065

Lecea, M., \& Perez-Stable, M. A. (2019). Success of reiterative instruction: Looking at facultylibrarian collaboration to improve information literacy in political science education. College \& Undergraduate Libraries, 26(1), 35-51. https://doi.org/10.1080/10691316.2019.1575305

Moore, T. (2013). Critical thinking: Seven definitions in search of a concept. Studies in Higher Education, 38(4), 506-522. https://doi.org/10.1080/03075079.2011.586995

Morra, L. M. (2014). Unarrested archives: Case studies in twentieth-century Canadian women's authorship. University of Toronto Press.

Morrissey, R., \& Given, L. (2006). International students and the academic library: A case study. Canadian Journal of Information and Library Science, 30(3-4), 221-39.

Natow, R. S., \& Dougherty, K. J. (2019). Performance funding as neoliberal policy. International Higher Education, (98), 7-8. https://ejournals.bc.edu/index.php/ihe/article/view/11181 
Neale, S. (2017). Screening the stage: Case studies of film adaptations of stage plays and musicals in the classical Hollywood era, 1914-1956. Herts, UK: John Libbey Publishing Ltd.

Nicholson, K. P. (2016). "Taking back" information literacy: Time and the one-shot in the neoliberal university. In N. Pagowsky, \& K. McElroy (Eds.). Critical library pedagogy handbook (pp. 25-40). Association of College and Research Libraries, a division of the American Library Association.

Perret, R. (2018, February). Mission critical? the presence of information literacy in academic library mission statements. Library Philosophy and Practice, 1-5. Retrieved from Research Library.

Popil, I. (2011). Promotion of critical thinking by using case studies as teaching method. Nurse Education Today, 31(2), 204-207. https://doi.org/10.1016/j.nedt.2010.06.002

Prescott, M.K. (2016). Using personal reflection to incorporate antiracist pedagogy in library instruction. In N. Pagowsky, \& K. McElroy (Eds.), Critical library pedagogy handbook (pp. 217-222). Association of College and Research Libraries, a division of the American Library Association.

Prud'homme-Généreux, A., Schiller, N. A., Wild, J. H., \& Herreid, C. F. (2017). Guidelines for producing videos to accompany flipped cases. Journal of College Science Teaching, 46(5), 40-48. Retrieved from Research Library; SciTech Premium Collection.

Saunders, L. (2017). Information literacy: What does it mean and where does it fit in? In J. M. Matarazzo, \& T. Pearlstein (Eds.), The Emerald Handbook of Modern Information Management (pp. 379-408). Bingley, UK: Emerald Publishing Limited.

Seale, M. (2016). Carrots in the brownies: Incorporating critical librarianship in unlikely places. In N. Pagowsky, \& K. McElroy (Eds.), Critical library pedagogy handbook (pp. 229232). Association of College and Research Libraries, a division of the American Library Association.

Shaw, R. D. (2014). How critical is critical thinking? Music Educators Journal, 101(2), 65-70. https://doi.org/10.1177/0027432114544376

Tobin, T.J., \& Behling, K.T. (2018). Reach everyone, teach everyone: Universal Design for Learning in higher education. Morgantown: West Virginia University Press.

Trembach, S., \& Deng, L. (2018). Understanding millennial learning in academic libraries: Learning styles, emerging technologies, and the efficacy of information literacy instruction. College \& Undergraduate Libraries, 25(3), 297-315. https://doi.org/10.1080/10691316.2018.1484835

Whitworth, A. (2014). Radical information literacy. Oxford: Chandos Publishing.

Woelert, P., \& McKenzie, L. (2018). Follow the money? How Australian universities replicate national performance-based funding mechanisms. Research Evaluation, 27(3), 184-195. https://doi.org/10.1093/reseval/rvy018 